\title{
Expelled members of Communist Party of Czechoslovakia Their careers and perspectives during the beginning of the Normalisation era in South Bohemia ${ }^{1}$
}

\section{MAREK JANSA}

Institute for the Study of Totalitarian Regimes,

Prague, The Czech Republic

e-mail: marek.jansa@ustrcr.cz

\section{Abstract}

The following study deals with those members of the Communist Party of Czechoslovakia (Komunistická strana Československa, KSČ) who had to face expulsion from the Party at the beginning of the 1970s. It aims to present the perspectives of

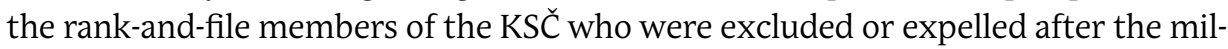
itary intervention of the Warsaw Pact troops in August 1968. Using the example of those expelled from two districts in South Bohemia (Český Krumlov and Prachatice), we will try to show the communist regime's principled openness to redress among those affected who demonstrated their loyalty to the regime. The Party sanction, or rather the hope of improving their disadvantaged position, thus motivated some of those affected to various expressions of loyalty, manifested not only in official requests for re-admission to the Communist Party, but above all through increased activity and public engagement. Also, many highly qualified workers were not significantly affected by the vetting due to their privileged status.

Key words:

Communist Party of Czechoslovakia (KSČ), Normalisation, expelled members, purges, 1970s, South Bohemia

1 The study was written with support of the individual grant project of the Grant Agency of the University of South Bohemia in České Budějovice No. 123/2021/H. 


\section{Šumava between the Prague Spring and so-called Normalisation}

The districts Český Krumlov and Prachatice are situated in South Bohemian borderland in the Šumava (Böhmerwald/Bohemian Forest) Mountains. They are regions located in the former Sudetenland, severely damaged by the post-war displacement of its German-speaking inhabitants. Despite intensive attempts and incentives to repopulate the area, it still struggled during the 1960s and 1970s with problems connected with such a massive population loss. It was very likely due to their geographical and demographical remoteness that the impact of the Prague Spring movement did not reach the borderland districts of Šumava with full intensity.

Nevertheless, this does not mean that the events in Prague or Brno did not resonate in the Šumava at all. Increased activity, civic engagement, the establishment of associations and magazines, and open criticism of all kinds can be observed among the population. These tendencies, however, also appear among members of the Communist Party of Czechoslovakia (Komunistická strana Československa, KSČ), both among rank-and-file members and among party officials. Many active members of the KSČ, encouraged by the developments among the Party elites, started to criticise not only commonly shared regional problems openly. Critique of local Party leadership members in both districts was also frequent due to its indifference to the process of democratisation associated with the Prague Spring.

Events following August 1968 and the fall of the Prague Spring accompanied the gradual emergence of a new power structure, which became known as so-called Normalisation. These changes took their toll in the form of many wasted careers, life expectations, exiles and other problems connected with the loss of Party legitimation. Since many of these fates are very well known, especially those of representatives of the Prague Spring and other eminent personalities, on the following pages, I am going to try to present varied perspectives and life trajectories of those inhabitants of the districts of Český Krumlov and Prachatice. They had to deal with their voluntary or forced exit from the KSČ in the early 1970s and the associated features of their lives and careers.

The research is based on sources from the provenance of Party organisations: district committees of the Communist Party of Czechoslovakia (Okresní výbor, OV KSČ), the South Bohemian Regional Committee of the KSČ (Jihočeský krajský výbor, JKV KSČ) and partially on data from the Central Committee of the Communist Party of Czechoslovakia (Ústřední výbor, ÚV KSČ) and Party congresses. Apart from documents produced directly by Party organs, the texts of appeals against party punishment were important for the research. These represent a remarkable and hitherto understudied source for understanding the fates, subjective insights, and dynamics of contemporary discourses and strategies of the excluded and those crossed out. 
Firstly, the study will try to present specifics of the so-called "purification" of the local Party organisations, starting with the process of spontaneous departures, motivated by disagreement with the military intervention of the Warsaw Pact troops as well as with the subsequent changes in the leadership of the KSČ. Subsequently, attention will be paid to the process of the expulsion and purging of KSČ members in chronological order - first in the leadership of the district organizations and then in the vetting of the rank-and-file membership. The final part of the article will focus on the phenomenon of appealing against Party punishments. Appeals were used by a number of those expelled and crossed out in an attempt to mitigate the adverse effects of their punishment. They were, of course, met with varying success depending, among other things, on the social background of the applicant. Thus, many of the unsuccessful ones resorted to alternative forms of demonstrating loyalty to the Normalisation regime.

\section{Leaving the Party}

A spontaneous exodus of the Communist Party members began immediately after the military intervention of the Warsaw Pact into Czechoslovakia in August 1968. Many of them terminated their Party membership as a demonstration of their disapproval of the intervention. Most of these demonstrative acts were held by the party-organised industrial and agricultural workers. This trend even intensified in April of the following year after Gustáv Husák replaced Alexander Dubček as General Secretary of the KSČ.

The rapid loss of numbers of workers after August 1968 dangerously deepened a tendency that the Party apparatus already carefully observed since the late 1940s: a reduction of the percentage of workers and farmers at the expense of the increasing number of civil servants, white-collar workers and professional Party functionaries. Party elites perceived this as a pressing problem for the Party, claiming to be the "vanguard of workers" and constructing its legitimacy on the worker's support. ${ }^{2}$ According to the Party materials, 568 members left the Party in Český Krumlov district in 1968-1970 (i.e., 10.2\% of all members of the Český Krumlov

2 Státní okresní archiv Prachatice (State district archives in Prachatice, hereinafter SOkA), f. (Fund) Okresní výbor KSČ Prachatice 1946-1989 (District Committee of the Communist Party of Czechoslovakia Prachatice) (OV KSČ), k. (Box) 29, Stručný výtah z rozboru současného stavu členské základny okresní organizace KSČ a předpoklad jejího dalšího třídního, sociálního a věkového vývoje do XV. sjezdu KSČ. Zpráva pro plenární zasedání OV KSČ 18. 2. 1972 v Prachaticích (A brief excerpt from an analysis of the current state of the membership base of the district organization of the KSČ and a forecast of its further class, social and age development up to XV. Congress of the KSČ. Report for the plenary session of the OV KSČ Prachatice, 18 February 1972); SOkA Český Krumlov (State district archives in Český Krumlov), f. Okresní výbor KSČ (OV KSČ) Český Krumlov 1945-1990 (District Committee of the KSČ Český Krumlov), k. 27, Sociální složení okresní organizace v porovnání od r. 1968 po výměnu legitimací (The social structure of the district organisation in comparative terms 1968-1970). Zpráva pro plenární zasedání OV KSČ Český Krumlov (Report for the plenary session of the OV KSČ Český Krumlov), 15. 12. 1970. 
Party organization in 1968). This number consisted of more than $60 \%$ of workers. The majority of whom quoted disagreement with the new Party leadership and disagreement with the August 1968 military intervention as a reason for leaving the Party. ${ }^{3}$

However, the demonstrative renunciation of party legitimacy was far from being just a series of individual expressions of disapproval of the Warsaw Pact intervention and the subsequent changes in the Party and the Republic leadership. During this time, several entire party organisations dissolved due to the mass withdrawal of members. To mention one example, the Basic Organisation of the Communist Party of Czechoslovakia (Základní organizace, ZO KSČ) in the Lipno Power Plant. The chairman of this organisation, František Petrouš, applied for the termination of his Party membership in June $1969 .^{4}$

In 1968, he was actively criticising the leadership of the District Committee of the Communist Party of Czechoslovakia Český Krumlov for its indifference to national developments. ${ }^{5} \mathrm{He}$ drafted a letter calling on all organisations in the district to call for a renewed conference to elect a new leading secretary of the district committee. After August 1968, he increased his critical activity when he repeatedly criticised gradual changes in the highest level of party leadership and government. According to the materials of the District Committee of the KSČ, he protested against the removal of the Prague Spring's prominent representatives (Ota Šik, Jiří Pelikán, Eduard Goldstücker and others) from public life. ${ }^{6}$

His demonstrative resignation caused a serious family split between František Petrouš and his father, a Communist Party member, since 1921. His resignation also led his eight other comrades to join him with his decision to leave the Party. Since the basic organisation originally consisted of 11 members, it dissolved due to the lack of members. Afterwards, František Petrouš had to leave his job at the Lipno Power Plant. Subsequently, he was offered a job as a technician at the new electrical substation in a small village near Prachatice, where he moved to a service house with his family. ${ }^{7}$

3 SOkA Český Krumlov, f. OV KSČ Český Krumlov 1945-1990, k. 48, Realizace usnesení lednového pléna ÚV KSČ z roku $1970 \mathrm{k}$ výměně stranických legitimací. Zpráva pro schůzi P[ředsednictva]OV KSČ Český Krumlov z 10. 9. 1970 (Implementation of the resolution of the January 1970 plenary session of the Central Committee of the KSČ on the exchange of party licences. Report for the meeting of the Communist Party of Czech Krumlov District Committee Chairing Board of 10 September 1970).

4 Státní oblastní archiv Třeboň (State regional archives in Třebon̆, hereinafter SOA), f. Jihočeský krajský výbor KSČ 1945-1990 (South Bohemian Regional Committee of the KSČ) (JKV KSČ), sv. (fasc.) 589, Stížnosti a připomínky, Žádost o potvrzení vyloučení Františka Petrouše z KSČ ze 7. 1. 1970 (Appeals and comments, Request for confirmation of the expulsion of František Petrouš from the Communist Party of Czechoslovakia dated 7 January 1970).

5 Party elites in Český Krumlov were also openly criticised in the local party press.

6 SOA Třeboň, f. JKV KSČ 1945-1990, sv. 589, Stížnosti a připomínky, Žádost o potvrzení vyloučení Františka Petrouše z KSČ ze 7. 1. 1970.

7 Ibid.; Author's archive, author's interview with Marie Králíková, 28. 2. 2021. 


\section{The Prachatice group}

The incapability of the district leadership to adapt to the new political direction of the Communist Party during the Prague Spring period was not only criticised by individuals. One of the few collective initiatives occurred during the extraordinary joint meeting of the Municipal Committee of the Communist Party of Czechoslovakia (Městský výbor, MV KSČ) Prachatice and the Council of the Municipal National Committee (Místní Národní výbor, MNV) taking place in the town of Prachatice on 25 March 1968. This extraordinary meeting, initiated Robert Marek, a lawyer and former secretary of the OV KSČ Prachatice. Its main aim was to come to an agreement leading towards a joint action against the current leadership of the OV KS $\breve{C}$ Prachatice, headed by its chief secretary, Karel Tondr.8

During the meeting that lasted through the night, its participants criticised the district leadership. The behaviour of the chief secretary Tondr was being described as absolute dictatorship..$^{9}$ In the morning, a letter addressed to him was finished and approved by those present. In the letter, Tondr was accused of obstructing the revival process and criticised for serious deformations and violations of the socialist legal order. He was further blamed for poor cadre work and abuse of office. ${ }^{10}$ Finally, Tondr, along with the district ideological secretary Jaromír Mazanec as well as with the ideological secretary of the South Bohemian Regional Committee of the Communist Party of Czechoslovakia Milan Mach-Žižka, lost a vote of no confidence and were asked to resign. ${ }^{11}$

The letter was published on the very next day in the daily regional newspaper Jihočeská Pravda. Two days later, the board of the district committee met over the letter together with the authors of the letter. One of them was Jan Oliva, the headmaster of the primary school in Prachatice and a long-time leading functionary of the Prachatice Communist Party. He, together with Prachatice district prosecutor Robert Marek and the director of the Prachatice Secondary Pedagogical School, Jan Mádl, were later identified by the Party's investigative commission as the main organisers of the whole event. ${ }^{12}$

In 1968 Oliva had already gone through a prosperous career. During the Second World War, he was forcibly deployed in Nazi Germany. Afterwards, in the late 1940s

8 Redakce: Komunisté v Českém Krumlově vyslovují nedůvěru vedoucímu tajemníkovi (Editors: Communists in Český Krumlov express distrust of the chief secretary). Jihočeská Pravda, 27. 3. 1968. p. 1.

9 Ibid.; SOkA Prachatice, f. OV KSČ Prachatice 1946-1989, k. 46, Zpráva komise o výsledcích stranického šetření Prachatické skupiny pro POV KSČ Prachatice (Report of the commission on the results of the party investigation of the Prachatice group for the POV of the KSČ Prachatice), 9. 2. 1970.

10 SOkA Prachatice, f. OV KSČ Prachatice 1946-1989, k. 46, Zpráva komise o výsledcích stranického šetření Prachatické skupiny pro POV KSČ Prachatice, 9. 2. 1970.

11 Ibid.; Redakce: Komunisté v Českém Krumlově vyslovují nedůvěru vedoucímu tajemníkovi, p. 1

12 SOkA Prachatice, f. OV KSČ Prachatice 1946-1989, k. 46, Zpráva komise o výsledcích stranického šetření Prachatické skupiny pro POV KSČ Prachatice, 9. 2. 1970. 
he graduated from the teachers' institute and subsequently worked as a teacher in eastern Bohemia. After his military service, he joined the KSČ. In March 1948, he was placed as a teacher in Volary, Prachatice district. From 1950-1952 he served as an army intelligence officer and during his service attained the rank of major. Until 1968 Oliva worked as the headmaster of the Primary School in Prachatice and as a Party official. He served as a head of the Party's education and later the ideological department in Prachatice and other positions. ${ }^{13}$

During the crucial meeting, Oliva allegedly acted as one of its organisers. However, at the meeting held two days later, he was the first to distance himself from the resolution and letter. He underwent self-criticism, and consequently, he condemns the whole protest action to failure. Among other things, his personal conflicts with other signatories, and especially to the already mentioned Robert Marek, is shown here. His aversion towards Marek has its roots in their previous clash since, in 1960, Marek had given Oliva a Party reprimand for abuse of office. ${ }^{14}$

To illustrate Oliva's ambiguous role within the local community it is useful to mention two letters. In the first one, members of the Communist Party organisation in Oliva's school protested against his candidacy to the JKV KSČ in June $1968 .{ }^{15}$ Oliva's colleagues protested against his autocratic methods of managing the school. They were also well aware of his abrupt changes of attitude and beliefs. The second letter was written by the very same members of the school's Party organisation in February 1970 and it was addressed to the District Committee of the Communist Party. In the letter, they tried to explain the role Oliva played during 1968 in order to clear his name. They argued that Oliva was influenced with the psychosis of the time. They also pointed out that he had sincerely regretted his misconduct. ${ }^{16}$

Oliva was expelled from the Party following disciplinary proceedings in February 1970. He subsequently had to leave his post as headmaster of the primary school in Prachatice. He worked briefly there as a teacher, but soon he had to leave the school altogether. After his forced departure, he found a job as a teacher at the school for children with special needs in Žíchovec near Prachatice. At that time, he was also stripped of his army rank. ${ }^{17}$

13 SOA Třebon̆, f. JKV KSČ České Budějovice 1945-1990, sv. 590, Odvolání Jana Olivy proti vyloučení ze strany (Jan Oliva's appeal against expulsion from the Party), 16. 4. 1970.

14 Oliva was punished for the abuse of his office when he assigned himself a car using his prominent position within the Party hierarchy. See Ibid.

15 SOkA Prachatice, f. OV KSČ Prachatice 1946-1989, k. 8, Rezoluce ZO KSČ při ZDŠ Zlatá Stezka v Prachaticích z 28. 6. 1968 a Dopis ZO KSČ při Pedagogické škole Prachatice z 12. 2. 1970 (Resolution of the Basic Organisation of the KSČ at the Zlatá Stezka Secondary School in Prachatice of June 28, 1968 and Letter of the Basic Organisation of the KSČ at the Pedagogical School in Prachatice of February 12, 1970).

16 SOkA Prachatice, f. OV KSČ Prachatice 1946-1989, k. 8, Dopis ZO KSČ při Pedagogické škole Prachatice z 12. 2. 1970.

17 SOA Třeboň, f. JKV KSČ České Budějovice 1945-1990, sv. 590, Odvolání Jana Olivy proti vyloučení ze strany, 16. 4. 1970. 
As a leading figure of so-called "right-wing opportunism" in Prachatice, the State Security Service (Státní bezpečnost, StB) became interested in him as early as 1970, emphasising his frequent contacts with other expellees from Prachatice and with former officials from regional and higher party instances. At the same time, the StB's initial report draws attention to his efforts to get involved in any part of the National Front ${ }^{18}$ and his opportunistic willingness to join with anyone if necessary. Another example of Oliva's persistent effort to reverse his fate is that he was able to finish his university education at the Faculty of Philosophy of Charles University during his engagement at the school in Žíchovec. ${ }^{19}$

At that time, Oliva was also listed by the StB as a candidate of secret cooperation (kandidát tajné spolupráce, KTS). Cooperation with the StB was another way to demonstrate loyalty to the new regime. For Oliva, however, a significant turning point came soon after, in 1974. He was forced to leave the education department for good by the decision of the Communist Party of Czechoslovakia's Central Committee and had to look for work as an unskilled labourer. Oliva was at first employed as a forest labourer, and after two months, he started to work as a blue-collar worker with Czechoslovakian Railways (Československé státní dráhy, ČSD) in Prachatice. This break (according to the StB materials) was to cause disillusionment in Oliva, which led him to completely cut off all contact and withdraw into private life with his second (and, as the StB materials point out, 23 years younger) wife and child. It was also at this point that the State Security lost their interest in his person. The possibility of using of Oliva as a secret collaborator made no sense, given his isolation. For the same reason, there was no longer a pressing need to monitor his potentially inappropriate influence on his co-workers. Unfortunately, nothing could be traced about his further fate..$^{20}$

\section{The Writer}

The fate of the writer Ivan Nový from Horní Planá represents a public intellectual's almost typical life trajectory in the second half of the 20th century. We will, therefore, briefly recall it here. Like Oliva, in 1968, Ivan Nový already had a long and rich party history. He had joined the KSČ in 1946. He had worked as a teacher in various places throughout the South Bohemian region. In 1956 he was expelled from the Party for a speech criticising the cult of personality. After a subsequent appeal, his sentence was reduced to a party reprimand. In the mid-1960's, he moved with his

18 Official broad-based coalition of all legal political parties as well as other non-political organisations (such as Revolutionary Trade Union Movement, Czech Red Cross or Union of Philatelists). National Front served as an instrument of KSČ to influence every legal organisation in Czechoslovakia.

19 Archiv bezpečnostních složek (Archive of Law-enforcement Agencies, hereinafter ABS), sb. (Collection) Svazky tajných spolupracovníků - České Budějovice (Files of secret collaborators - České Budějovice) (TS/CB), sv. (File) a. č. (archival number) 8089, Jan Oliva.

Ibid. 
family to Horní Planá, district Český Krumlov, where he served as headmaster, later deputy headmaster of the local primary school. ${ }^{21}$

Along with his professional career, he was also active as an author. Until 1970 he published several books for children and several works of fiction inspired by his experiences with the Šumava countryside..$^{22}$ To have time to write, Nový left his post as deputy at the secondary school and was granted a year's "creative leave". He became politically active again during 1968 when he was elected as a delegate to the XIVth (so-called Vysočany) ${ }^{23}$ Congress of the KSČ. Because of his pro-Prague Spring activity and his critical statements about Gustáv Husák and the changes he represented, he was dismissed from the JKV KSČ in 1969. He was then finally expelled from the Party in April 1970. ${ }^{24}$

After his expulsion from the Communist Party, Nový voluntarily left his teaching job at the Horní Planá primary school. According to StB materials, Nový did so to avoid the humiliation of being reclassified from deputy headmaster to a mere teacher. ${ }^{25}$ Due to his cadre profile, he was not allowed to take up a job that matched his qualifications, and he was therefore forced to take a job with the ČSD as a railway worker. Later, for health reasons (tremor of hands), he was transferred to the position of an errand boy.

According to the StB materials, kept on him under the code name "Writer" (Spisovatel), as well as according to the memories of his daughter Věra Nová, Ivan Nový soon retreated to the privacy of his cottage in a secluded area near the Pěkná train station in the Šumava, on the very edge of the secured border zone. He bought the cottage together with another expelled colleague of his. After his expulsion, he avoided staying in Horní Planá and practically lost most of his contacts with former colleagues and friends. Apart from his career difficulties, his publishing activities were stopped and banned. There was only one alleged exception when he had maintained publishing a short article in a fishing magazine in Český Krumlov, which, however, caused him as well as editors of the magazine many other unpleasantries. However, this did not prevent him from writing, some of his typescripts circulated among a small circle of relatives and friends. ${ }^{26}$

$21 A B S$, sb. Svazky kontrarozvědného rozpracování - České Budějovice (Files of counterintelligence elaboration) (KR/CB), sv. a. č. 3799, Ivan Nový. Nový was enlisted by the State Security's materials as a person hostile to the regime.

22 Until 1970 Nový published children's books Davídek (Nakladatelství České Budějovice, České Budějovice 1966) and Davídek doma a ve škole (Růže, České Budějovice 1970) and also books Na rybářské stezce (Nakladatelství České Budějovice, České Budějovice 1964) and Rybářské toulky (Nakladatelství České Budějovice, České Budějovice 1965) inspired by his fishing experiences.

23 Extraordinary Congress held from August 26 to 281968 and later invalidated.

24 SOA Třeboň, f. JKV KSČ České Budějovice 1945-1990, sv. 592, Připomínky a stížnosti, Žádost o potvrzení vyloučení Ivana Nového z KSČ (Comments and complaints, Request for confirmation of Ivan Nový's expulsion from the KSČ), 4. 5. 1970.

$25 A B S$, sb. KR/CB, sv. a. č. 3799, Ivan Nový.

26 Ibid. 
The cottage near Pěkná became a regular meeting place for a group of friends and sympathisers. Given the status of the visitors, many of whom were similarly party-afflicted as Nový, the meetings were closely supervised by members of the StB and Border Guard (Pohraniční stráž, PS). The exact location of Nový's cottage near the state border, moreover, encouraged vigilance.

State Security officers concluded soon that the regular meetings at the cottage were of a social rather than political nature. Therefore, it did not pose a danger to the already consolidated Normalisation regime. So, it is evidenced by the final report from the Nový's file by the StB. It states that Novy's contacts were of a friendly nature, associated with drinking alcohol and telling anecdotes, at which point the file was closed and the surveillance terminated. However, the partial publication of Novy's work could not take place until after November 1989, and some of his works are still awaiting publication today, more than 17 years after his death. ${ }^{27}$

\section{Party Purges}

The new state of affairs represented by the new party leadership after April 1969 needed to be supported by a united mass party. Therefore, it was not sufficient to proceed only with the changes on the highest level of the party hierarchy. For this reason, it was decided to carry out a large-scale screening operation, during which the KSČ would be cleared of the Prague Spring supporters and opponents of the new leadership. The regular exchange of party legitimations, which were already postponed several times, was chosen for this occasion. The KSČ underwent this exchange regularly within approximately ten-year intervals. It usually helped the Party administration eliminate irregularities in the fulfilment of Party duties (especially the payment of party dues, subscription to the party press and attendance at meetings) and eventually eliminate or discipline those inactive or unruly members. ${ }^{28}$

In order to discipline members, the KSČ apparatus evolved a diverse hierarchy of punishments over the years, from a party reprimand to the severest punishment of expulsion. The expulsion was imposed for major offences against Party discipline. The exchange of Party legitimations in 1970 focused primarily on ideological issues, and screening committees were given the task of ascertaining and assessing the attitudes and activities of interviewees during 1968, their opinion of the intervention of Warsaw Pact troops and the new party leadership. There were then only three possible outcomes - the return or exchange of party legitimation and crossing out and expulsion from the Party. ${ }^{29}$

27 Ibid.; Author's archive, author's interview with Karel Postl, 28. 4. 2018.

28 See ČERNÁ, Marie et al.: Prověrky a jejich místo v komunistickém vládnutí. Československo 1948-1989 (Clearances and their role within the communist governance. Czechoslovakia 1948-1989). Ústav pro soudobé dějiny AV ČR, Praha 2012.

29 Crossing out of the Party was a punishment meant to be used in cases of minor offenses, it was also often followed with less severe consequences than in the case of expelled members. Among 
Party purges in 1970 became an essential instrument of power transition in Czechoslovakia. The subsequent screenings with non-Party-members proceeded by their employers played a decisive role in the final defeat of the Prague Spring and the beginning of the twenty years of so-called Normalisation.

All of the 1.5 million Communist Party members were immediately affected by the vetting process. More than 300,000 members who were crossed out or expelled from the Party did not pass through the screening commissions. In relative terms, $21.7 \%$ of members were lost $-17.2 \%$ crossed out, and $4.5 \%$ expelled. ${ }^{30}$ The South Bohemian Region was slightly above the average in these tabulated figures, with $22.5 \%$ of those expelled and crossed out. ${ }^{31}$

There was a similar situation in both districts of Český Krumlov and Prachatice, where Communist Party members were overrepresented in proportion to the total population when compared to the Czechoslovakian average. In the Prachatice district, 4,026 members (79.5\%) of the original 5,251 members were issued with a new legitimation. There were 786 persons (15.5\%) crossed out and 251 (5\%) expelled, i.e., a total of 1,037 legitimations were not issued. In addition, 123 persons had their membership revoked without being interviewed. On 10 September 1970 there were 4,139 Party members, i.e., about $78.8 \%$ of the number at the beginning of the year.

In the Český Krumlov district, out of a total of 4,871 members, 163 (3.3\%) were expelled on 1 January 1970, and there were 1,031 (21.16\%) members crossed out. In total, the district organisation lost $24.5 \%$ of its Party members. In the autumn

other things, it provided the crossed-out member with a greater chance of "rehabilitation" and eventual return to the Party. For more on purging in Czechoslovakia, see Ibid.; MAŇÁK, Jiŕi: Čistky v Komunistické straně Československa v letech 1969-1970 (Purges in the Communist Party of Czechoslovakia, 1969-1970). Ústav pro soudobé dějiny AV ČR, Praha 1997. From more recent literature see KOCIAN, Jiří a kol.: Dějiny Komunistické strany Československa IV (1969-1993) (History of Communist Party of Czechoslovakia, Vol. IV /1969-1993/). Academia, Praha 2020. So far, there is a minimum of studies dealing with Party purges and the introduction of Normalisation at the regional level that would provide interregional comparison. See MAŇÁK, Jiří: Od ústupu k porážce, od omezování k likvidaci. Postup "normalizace a jeho vyvrcholení v „očistě “ liberecké okresní organizace Komunistické strany Československa (From retreat to defeat, from restriction to destruction. The process of "normalization" and its culmination in the "cleansing" of the Liberec district organisation of the Communist Party of Czechoslovakia). Ústav pro soudobé dějiny AVČR, Praha 2011; SKALECKÁ, Veronika: Pardubice v období normalizace. Politika, kultura a média od srpna 1968 do listopadu 1989 (Pardubice during the normalization period. Politics, culture and media between august 1968 and November 1989). Pavel Mervart, Červený Kostelec 2016. For more on purging in Slovakia see SIKORA, Stanislav: Zo strany von! Čistky radového členstva KSČ na Slovensku roku 1970 (Out of the Party! Purges of rank-and-file members of the KSČ in Slovakia 1970). In: ROGUL'OVÁ, Jaroslava a kol.: Adepti moci a úspechu: Etablovanie elít v moderných dejinách. Jubileum Valeriána Bystrického (Adepts of Power and Success. Establishment of Elites in Modern History. The Jubilee of Valerian Bystrický). Veda, Bratislava 2016.

30 MAŇÁK, Jiř́: Čistky v Komunistické straně Československa v letech 1969-1970, p. 58.

31 SOkA Český Krumlov, f. OV KSČ Český Krumlov 1945-1990, k. 48, Zhodnocení výměny stranických legitimací v okrese Prachatice v roce 1970, Zpráva pro schůzi POV KSČ Prachatice dne 14. 9. 1970 (Evaluation of the Exchange of Party Legitimation in the Prachatice district in 1970, Report for the meeting of the chairing board of the OV KSČ on September 14, 1970). 
of 1970, 3,634 members remained in the Český Krumlov organisation, i.e., 74.6\% of the number at the beginning of the year. ${ }^{32}$

Party punishments were handed out mainly for incorrect ideological positions and inappropriate behaviour. However, traditional disciplinary offences were also punished, not only against party regulations but, of course, also against the laws of the republic. This is demonstrated by the example of Bohumil Blovsky, the former economic deputy of the State Farm (Státní statek) Volary, who was expelled from the KSČ for manipulating funds paid out for socialist competition. He was subsequently transferred to the same position at the Horní Vltavice farm, where he was to remain until the restructuring of the State Farms. Similarly, Miloslav Dragoun, the chairman of the Agricultural Cooperative (Jednotné zemědělské družstvo, JZD) Čkyně, was expelled from the KSČ for corruption by a vetting committee. One of those expelled as early as 1969 was Blažena Sovová, a worker in the apparatus of the KSČ in Prachatice, who was also expelled for embezzlement of funds. ${ }^{33}$

\section{Turner in the Central Committee}

During 1968, Václav Šimeček, a turner at the Jihostroj Velešín plant and drummer of the Budvarka band from České Budějovice, was the only KSČ member from our area to reach the top rung of the party hierarchy. At the XIV. (Vysočany) Congress of the Communist Party of Czechoslovakia, he was co-opted to the Bureau of the ÚV KSČ as one of only two workers. Since the "purging" of the party apparatus proceeded from the top of the party hierarchy downwards (i.e., from the Central Committee through the regional committees to the district committees and then to the rank-and-file through the Purges), the members of the ÚV KSČ were naturally the first in line.

Václav Šimeček, like other top representatives of the Prague Spring, was a thorn in the side of the incoming normalisation authorities. In 1969 he resigned from his positions in the Party Central Committee, and then he left his functions in the

32 In both districts total numbers of expelled and those crossed out consisted of approx. 30\% of workers and $40 \%$ of technical and economical workers including teachers. The above-average numbers of workers can be explained by the significant representation of agricultural workers (workers on state farms) within the membership of the Communist Party in the Šumava. See Ibid., Realizace usnesení lednového pléna ÚV KSČ z roku 1970 k výměně stranických legitimací. Zpráva pro schůzi POV KSČ Český Krumlov z 10. 9. 1970 (Implementation of the resolution of the January 1970 plenary session of the ÚV KSČ on the exchange of party licences. Report for the meeting of the chairing board of the OV KSČ Český Krumlov of September 10, 1970).

33 SOkA Prachatice, f. OV KSČ Prachatice 1946-1989, k. 99, Informativní zpráva o řešení kádrů v nomenklaturních funkcích po skončení výměny stranických průkazů pro schůzi POV KSČ v Prachaticích 12. 10. 1970 (Informative report on the treatment of cadres in nomenclature positions after the end of the exchange of party cards for the meeting of the chairing board of the OV KSČ Prachatice); Ibid., k. 199, Rozbor vývoje členské základny okresní organizace za léta 1967, 1968, 1969. Zpráva pro schůzi OKRK Prachatice (Analysis of the development of the membership base of the district organization for 1967, 1968, 1969. Report for the meeting of OKRK Prachatice), 21. 1. 1970. 
Regional Party Committee. Subsequently, he had to leave the Party Committee at Jihostroj Velešín (the factory where he worked for his whole life as a turner) and was finally expelled from the KSČ for good during the screening interviews for the Party purges. ${ }^{34}$

As he was still employed as a worker during his involvement with the Central Committee, his expulsion did not result in any significant career downgrade. However, as a former worker member of the Bureau of the Central Committee of the Communist Party of Czechoslovakia, he was subjected to surveillance and pressure from Party officials and the StB for ideological reasons. The latter tried to force him into public self-criticism and condemnation of his participation within the Prague Spring movement.

The secret police finally succeeded with the threats of banning Šimeček from travelling abroad with his band as well as preventing one of his sons from studying law and another from teaching. Under pressure, he published an article in the daily newspaper Práce in September 1973. In the article, Šimeček made a kind of self-criticism. He also condemned the Prague Spring Party leadership represented by Alexander Dubček and described himself as a manipulated instrument for the enforcement of Dubček's post-January policy. In his own words, Šimeček was particularly valuable for Dubček's leadership because he was a worker and could thus serve as a better example than professional Party officials. ${ }^{35}$

After the article was published, the StB threatening and pressure stopped, Šimeček continued participating in trips with the band to Germany and other Western European countries until he died in the second half of the $1980 \mathrm{~s}^{36}$

\section{Appeals against the expulsions from the Party}

As we have already seen from previous examples, many former party members disagreed with their expulsion and decided to defend themselves against the verdict. The Party rules provided their members with formal procedures for such cases. Suppose a Party member disagreed with the proposed or already imposed disciplinary punishment. In that case, they could appeal to the nearest superior party body or request a new investigation of their case. ${ }^{37}$ In case of its positive outcome, the

34 Without giving up his work as a worker, Šimeček worked in various party functions from 1948 onwards, serving as a member of the Factory Committee of the KSČ (Celozávodní výbor, CZV KSČ) at Jihostroj Velešín, the MV KSČ, a member of the JKV KSČ from 1960, and a member of various committees, at the XIII. Congress of the KSČ. He was elected a candidate of the Communist Party of Czechoslovakia Central Committee. In addition, he was a drummer in the famous České Budějovice brass band Budvarka. See SOA Třeboň, f. JKV KSČ České Budějovice 1945-1990, sv. 594, Žádost o potvrzení vyloučení Václava Šimečka z KSČ z 9. 7. 1970 (Request for confirmation of Václav Šimeček's expulsion from the KSČ dated 9 July 1970); Author's archive, author's interview with Vladimír Šimeček, 27. 1. 2019.

35 Author's archive, author's interview with Vladimír Šimeček, 27. 1. 2019.

36 Ibid.

37 Stanovy Komunistické strany Československa schválené 12. sjezdem KSČ dne 8. prosince 1962, 
appeal was resolved with the revocation of the committee's decision. In such cases, the hierarchy of penalties was generally respected. That is to say, the expelled applicant was reclassified as a crossed-out. Crossed-out members were reinstated as the KSČ members.

Appeals were an established process within the Party. Anyone could exercise this right within one month from the time sentence being imposed. The appeal had to be investigated by a specialised Party organ established to control and audit its functioning on every level of the Party hierarchy. For obvious reasons, there had been a rapid increase in appeals numbers starting in late 1969 and especially after the Party purges. Both the quantity and content of those appeals make it an exciting source for the purpose of historical research of the early Normalisation period.

Appealing was indeed a mass phenomenon evidenced by the numbers presented by the chairman of the Central Audit and Revision Commission (Ústřední kontrolní a revizní komise, ÚKRK) Miloš Jakeš during the XVth Congress of the KSČ, held in April 1976. These show the significant interest of the excluded in rehabilitation. Jakeš states here that a total of 64,926 former members were appealing. According to these figures, therefore, a total of $18.3 \%$ of all former members underwent their appeal. In relative terms $7.9 \%$ of those crossed out appealed against their punishment and even $65.5 \%$ of those who were expelled! Subsequently, 10.1\% of these appeals were resolved positively, of which 3,913 were reinstated, and in 2,623 cases, the expulsion was changed to crossing out. In the same speech, Jakeš then declares the six-year-long process of appeals to be definitively over. ${ }^{38}$

The process of appealing against the results of Party purges did not only follow the official path of appeals outlined above. According to the reports and records of the OV KSČ chairing board meetings, many complaints and appeals were resolved only through oral channels. Many of them also had different addressees than those prescribed in the Party statutes. Individuals often appealed directly to the central authorities, not only to the ÚKRK, but also to the ÚV KSČ, or individual representatives of the central Party and state authorities (especially Gustáv Husák, Miloš Jakeš and President Ludvík Svoboda). The editorial of Rudé Právo and other party periodicals were also popular.

The information from the regional level is drawn from a report summarising the status of appeals as of 1 September 1972. Still, the number of appeals here did not change significantly in subsequent years, and therefore an approximate comparison can be afforded. By September 1972, the South Bohemian regional Party Committee had received 111 appeals against expulsion, accounting for 3.6\% of all those expelled, and 33 appeals against the crossing out, i.e., $0.2 \%$. Appeals in both

doplněné a upravené 13. sjezdem KSČ dne 4. června 1966 (Statutes of the KSČ approved by XII. Congress of the KSČ on December 8, 1962, supplemented and modified by XIII. Congress of the KSČ). ÚV KSČ, Praha 1966, kapitola (Chapter) I, čl. (point) 13, p. 19.

38 Sbornik hlavních dokumentů XV. sjezdu KSČ 12.-16. dubna 1976 (Proceedings of the main documents of the XVth Congress of the KSČ 12-16 April 1976). Svoboda, Praha 1976, p. 91. 
categories were most frequently lodged by employees classified as technical and economic workers, and in a very striking proportion, accounting for more than $65 \%$ of expulsion appeals and more than $50 \%$ of crossing-out appeals. ${ }^{39}$

The content of many appeals can be described by a comment made by an anonymous party official in an attempt to summarise the case of expelled agronomist from Kaplice František Ondřich who was later re-admitted as a Party member: $\mathrm{He}$ had an opinion on it. In hindsight, however, he realised that he had not viewed the whole thing correctly. ${ }^{40}$ Since many expelled offenders repeatedly appealed their punishments, we can trace a variety of negotiating strategies employed in the texts. Along with other complaints, the comments or denunciations provide us with essential materials while also focusing on discursive shifts from the Prague Spring period towards Normalisation while tracing sources of their legitimisation and delegitimisation.

Naturally, the exclusion and crossing out of the Party did not avoid the district officials either. Although the District Committees of the Communist Party of Czechoslovakia in Český Krumlov and Prachatice did not undergo any dizzying changes after August 1969, they were not without significant personnel changes. One of the important district officials in Český Krumlov for practically the entire 1960s until August 1969 was Ing. František Šedivý.

Šedivý had worked in the district committee apparatus since 1958, first as an instructor, and from 1963 he had held the position of Secretary of the OV KSČ Český Krumlov for Agriculture. He left this position in August 1969 due to disputes with the chief secretary of the OV KSČ Český Krumlov, Adolf Chrt. In reports summarising the development in the district, he was subsequently described as one of the leading "right-wingers" in the district; he was expelled in July 1970 during the Party Purges. ${ }^{41}$

He then appealed this decision to the District Party Audit and Revision Committee (Okresní kontrolní a revizní komise, OKRK). In his appeal, he admitted, among other things, that he did not understand the necessity of military intervention in August 1968 and that this may have had a negative effect on his work. However, he attributes this error to a lack of information. The OKRK dismissed the appeal, pointing out that the exclusion had been approved at the regional level. According

39 SOA Třeboň, f. JKV KSČ České Budějovice 1945-1990, sv. 484, Statistický přehled odvolání a stížností k výsledkủm výměny členských legitimací za období 1970 - srpen 1972 k 1. 9.1972 (Statistical summary of appeals and complaints on the results of the exchange of membership cards for the period 1970 - August 1972, dated September 1, 1972).

40 SOkA Český Krumlov, f. OV KSČ Český Krumlov 1945-1990, k. 75, Materiál k přijetí kandidatury [členství ve straně] Františka Ondřicha. Zpráva pro schůzi POV KSČ Český Krumlov (Material on the acceptance of the candidacy of [party membership] of František Ondřich. Report for the meeting of the chairing board of the OV KSČ Český Krumlov), 27. 12. 1976.

41 SOA Třeboň, f. JKV KSČ České Budějovice 1945-1990, sv. 600, Stížnosti a připomínky. Odvolání Ing. Františka Šedivého proti vyloučení ze strany z 25. 11. 1970 (Complaints and comments. Appeal of Ing. František Šedivý against expulsion from the Party dated November 25, 1970). 
to the archival material, it appears that Šedivý did not try to fight his disqualification officially any further. As if the party sanction was not enough, František Šedivý was even subsequently selected by the regional committee for inclusion in the so-called Central Register of Exponents of the Right (Centrální evidence představitelů, exponentů a nositelů pravicového oportunismu, organizátorů protistranických, protisocialistických a protisovětských kampaní a akcí v kádrové evidenci ÚV KSČ). After he began to be monitored by the StB, Šedivý was reassigned to the position of an independent clerk, from which he could no longer influence his co-workers. Although his file was deposited in the archives in 1986, Šedivý was retained in the Central Register. ${ }^{42}$

\section{Workers and peasants}

We have mentioned the caution with which the party apparatus approached the decline of its worker and peasant members. In the course of the Party's 1970 inspections, we can speak without much exaggeration directly of positive discrimination against workers and members of the agricultural cooperatives. At least, that is how we can explain the case of Josef Havír, who worked as an agricultural worker in 1970.

Josef Haviŕ repeatedly failed to appear for a screening interview on the due date and was thus excluded by the screening committee. However, he soon appealed against this decision and was one of the few whose appeal was upheld. He gives a rather curious list of why he could not attend the purging interview in his appeal. He was unable to participate on the first date because he was getting married. The alternative date set by the screening committee was also not a good time because, in Haviŕr's words, it was a sunny day, and he did not want to miss work.

From today's perspective, it is difficult to say whether the appeal board was more impressed by a happy life event or by Havír's zeal for work. However, the panel evaluating the appeal concluded that since he is an agricultural worker, the question of his membership should be reconsidered. ${ }^{43}$

\section{Doctors}

During the Party purges, the KSČ lost a significant number of doctors and other medical staff, among others. In total, more than $35 \%$ of all party-organised doctors in the South Bohemian region were expelled. It is also necessary to mention that borderland areas such as those inquired had suffered long from an alarming short-

42 Ibid. Central register was a list of more than 6,000 representatives of the Prague Spring and other persons hostile to the regime, compiled at the initiative of the ÚV KSČ between 1971 and 1973.

43 SOkA Prachatice, f. OV KSČ Prachatice 1946-1989, k. 99, Šetření stížnosti s. Haviŕre Josefa. Zpráva pro schůzi POV KSČ Prachatice dne 14. 9. 1970 (Investigation of the complaint of Mr. Haviŕ Josef. Report for meeting of the POV KSČ Prachatice of 14. 9. 1970). 
age of doctors and medical staff. For this reason, it was unthinkable to use the same measures in cadre politics for doctors as for other professions. Because the local Party authorities were engaged in various ways to attract doctors to the region, they could not simply afford to lose any of them because of their cadre profile.

It was not only rank-and-file doctors who were concerned but medical functionaries also. As it is suggested by a report from 1980: It is not always possible to follow the general requirements for professional and political qualifications. There is a situation where there is no one from our own cadres who meets both requirements. ${ }^{44}$ According to a report of the Regional Institute of National Health (Krajský ústav národního zdraví, KÚNZ) evaluating political work, at the end of the 1970's the situation of the health department in Prachatice was rated as the worst in the region. Only 12 out of the 125 doctors in its jurisdiction were organised in the KSČ. ${ }^{45}$

One of the few doctors who decided to appeal against the results of the Party purges was MUDr. Zdeněk Ziegrosser. He graduated from medical school in 1953, and in 1957 he accepted the offer of membership in the Communist Party of Czechoslovakia. He worked as a secondary physician and then as a deputy to the District Institute of National Health (Obvodní ústav národního zdraví, OÚNZ) chairman in Prachatice. During the 1960s, he was appointed as a candidate for deployment in the UN medical aid. At the same time, he held the head of the health department at the OV KSČ in Prachatice. ${ }^{46}$

During the Party purges, he was expelled from the Party because of his opinions. As already mentioned, he immediately, but unsuccessfully, appealed against this decision. In the following period, he was among those proposed for the Central Register of Exponents of the Right as a hostile person like Oliva or Nový. After his expulsion from the KSČ, he was soon dismissed from the previous positions with the Party and with the OÚNZ.

Immediately afterwards, however, he was appointed director of the Orphanage in Husinec near Prachatice. He successfully served in this position until the end of the 1980s. Despite his expulsion and classification as a person hostile to the regime, MUDr. Ziegrosser held the long-exposed position of director of the Children's Home in Husinec. In his practice, he significantly contributed to the development of health care in the Prachatice countryside. On his initiative, the first mobile children's clinic (Dětská pojízdná poradna) was introduced in the Prachatice region in the mid-1980s. ${ }^{47}$

44 Ibid., k. 96, Zpráva o stavu kádrové práce na OÚNZ Prachatice z 8. 9.1980 (Report on the state of personnel work at the OÚNZ Prachatice, 8 September 1980).

45 Ibid.

46 SOkA Prachatice, f. Okresní národní výbor (District national committee) (ONV) Prachatice (1919) 1945-1990, k. 109, Osobní spisy zaměstnanců ONV Prachatice, Osobní spis MUDr. Zdeňka Ziegrossera (Personal files of ONV Prachatice employees, Personal file of MUDr. Zdeněk Ziegrosser).

47 Report of Czechoslovakian Television (ČST) from 23. 9. 1984 - see http://www.ceskatelevize.cz/ ivysilani/10132488909-pred-25-lety/209411000110923/ (quoted version dated 24. 11. 2021). 
The career of MUDr. Julius Mattauch had a much more straightforward development. Even after his expulsion, he remained in the chairman of the dental department with the OÚNZ in Prachatice. The same applies to the (also expelled) head of the X-ray department at Prachatice Hospital, MUDr. Vladimír Kovařík. ${ }^{48}$

MUDr. Jan Mager, another doctor from Prachatice hospital, joined the KSČ in 1964. After graduating from the Faculty of Medicine of Charles University in Pilsen, he joined the hospital's surgical department in Prachatice. In 1969 he was appointed deputy head of the surgical department. In 1970, Party suspended his membership. He refused to apply for an interview and was expelled from the KSČ. This fact, however, did not prevent him from further professional training in hospitals in České Budějovice and Prague (Bulovka Hospital and Střešovice Hospital), after which he passed the second-degree certificate in surgery in 1979. The following year he was appointed head and then chief of the surgical department of the Prachatice hospital. He remained in this position until his disability retirement in the early 1990 s. $^{49}$

\section{Return to the Party}

The fate of Josef Šafránek, an educator and psychologist from Prachatice, testifies that even being expelled did not necessarily mean the inevitable end of party involvement. Šafránek served for a long time as principal of the Zlatá Stezka Primary School in Prachatice. He remained in this position after his crossing out of the Communist Party during the purges (unlike many similarly affected colleagues). Materials of the ÚV KSČ justified this move because no replacement could be found..$^{50}$ He remained as principal until the end of the 1976 school year. During this time, he completed his education in special pedagogy. After being released from his position as principal, he could join the District Pedagogical and Psychological Counselling Centre (Okresní pedagogicko-psychologická poradna) as a special educator. He was very successful in this practice. According to the 1981 Comprehensive Cadre Evaluation, he is credited with major contributions to the development of speech therapy and care for children with sensory impairments. ${ }^{51}$

After his removal, Šafránek continued to be very active in public life, not least in his role as headmaster. He worked as a lecturer in political education for non-

48 SOkA Prachatice, f. ONV Prachatice (1919) 1945-1990, k. 42, Osobní spisy zaměstnanců ONV Prachatice, Osobní spis MUDr. Vladimíra Kovaříka (Personal files of ONV Prachatice employees, Personal file of MUDr. Vladimír Kovařík).

49 SOA Třeboň, f. JKV KSČ České Budějovice 1945-1990, sv. 442, Pohovorové listy k Výměně členských legitimací OV KSČ Prachatice (Interview sheets for the exchange of membership cards of the Communist Party of Czechoslovakia Prachatice); Jan Mager's CV - see http://www.prachatice.eu/ mudr-jan-antonin-mager/d-21065 (quoted version dated 24. 11. 2021).

50 SOkA Prachatice, f. ONV Prachatice (1919) 1945-1990, k. 87, Osobní spisy zaměstnanců ONV Prachatice, Osobní spis Josefa Šafránka (Personal files of ONV Prachatice employees, Personal file of Josef Šafránek).

51 Ibid. 
-partisan teachers and chairman of the Cabinet of Didactic Techniques (Kabinet didaktické techniky) at the district pedagogical centre. He was the chairman of the Revolutionary Trade Union Movement committee (Revoluční odborové hnutí, $\mathrm{ROH})$ and also active member of several other organisations. He was also elected three times in a row as a deputy of the Prachatice MNV. As part of his parliamentary mandate, he served as chairman of the finance and planning committee. According to all those involved in the membership renewal process, nothing could prevent his re-admission as a candidate in 1976 and as a member of the Communist Party the following year. ${ }^{52}$

However, the period when re-admission began to occur to a greater extent did not happen until after the XVIth Congress of the KSČ in April 1976. Congress opened up the possibility of re-admission based on the principle of differentiated access. It was thus now up to the apparatus of the basic and district organisations to assess which of those expelled were "genuine enemies" of the Party and which had proved by their behaviour to be worthy of re-joining the party ranks. Suitable applications for re-admission to the KSČ were selected on the basis of discussions between the apparatus of the district committees and the committees of the basic organisations. Subsequently, comprehensive assessments were made of the selected applicants - this collected information on employment activity, social and political involvement, and family life.

In Prachatice, at a meeting of the Chairing board of the OV KSČ on December 27, 1976, it was decided to admit 5 out of 22 applicants; in Český Krumlov, on the same day, it was agreed to readmit 3 out of 9 applicants. Furthermore, the Bureau approved a plan to admit a maximum of 5 applicants for re-admission each year. Although the actual numbers of re-admissions were by no means extensive, the very fact that this admission was possible and even sanctified by the Party Congress may have had a strong psychological effect on some of those excluded.

Similar public involvement can be observed in other expelled persons who were readmitted as candidates of Party membership after 1976. In fact, in 1976, the XVth Congress of the KSČ approved the possibility of readmitting as members those who had been expelled or struck off during the 1970 vetting process. It thus gave the chance of satisfaction to those "less guilty" who had sufficiently realised their earlier "misconduct". 53

A high level of commitment is a feature that unites all the approved candidates for re-admission to the Party. Similarly, for example, Bohumil Kasl, the driver of

52 SOkA Prachatice, f. OV KSČ Prachatice 1946-1989, k. 99, Informativní zpráva o řešení kádrů v nomenklaturních funkcích po skončení výměny stranických průkazů. Zpráva pro schůzi POV KSČ Prachatice (Informative report on the treatment of cadres in nomenclature positions after the end of the exchange of party cards. Report for the meeting of the chairing board of the OV KSČ Prachatice), 12. 10. 1970.

53 Ibid., k. 75, Potvrzení přihlášek bývalých členů strany za kandidáty KSČ. Zpráva pro jednání POV KSČ Prachatice (Confirmation of applications of former party members as candidates of the KSČ. Report for the meeting of the chairing board of the OV KSČ Prachatice), 27. 12. 1976. 
the textile company Jitona Vimperk who was crossed-out of the KSČ, had long held the chairman of the ROH. He was also a member of the hunting association called Žár (Heat). Another readmitted, Jaroslav Jirka, a technician of the Loučovice paper mills, was repeatedly elected as the Loučovice MNV deputy. He was also involved in other quasi-political organisations. ${ }^{54}$

František Ondřich was proposed for expulsion from the KSČ by the interview committee because he refused to accept the official stance on the 1968 military intervention, and he also refused the figure of Gustáv Husák as the Party's new general secretary. This was subsequently changed to expulsion during the approval process. He worked as the chief agronomist of the JZD Kaplice and applied for re-admission in 1976. Until then, he was involved in the ROH organisation as a chairman. He was also involved in other organisations. ${ }^{55}$

The story of Milada Kalinová, a teacher at the Husinec Secondary School who was expelled, shows that family relations may have played an essential role in the process of re-admission. She was accepted as a candidate for the KSČ in September 1980. Her husband was a long-time chairman of the town council in Husinec and a MNV member. However, Václav Šnelcr, the father of Kalinová, a pre-war party member, was instrumental in her re-admission. ${ }^{56}$

\section{State Security Service}

As we have already seen, there were various ways to show loyalty to the Normalisation regime. We can move now from multiple forms of civic activity and social engagement to activities that may seem more morally problematic from today's perspective. Cooperation with the StB as one of the ways to gain attention was described in the story of Jan Oliva. Now we will shortly focus on some others.

After JUDr. Antonín Hrach was expelled from the Party, he was forced to resign as district prosecutor at the Prachatice district. Surprisingly, he took a similar position when he became district prosecutor in the neighbouring district of Strakonice. He was employed there until 1975, when was forced to leave. "Right-wing" activities and his expulsion in 1970 justified his dismissal, but the real motivation could not be traced. Hrach subsequently accepted a position as a lawyer at the District Agricultural Administration (Okresní zemědělská správa) in Strakonice. He was recruited to cooperate with the State Security Service in September 1980 to

54 SOkA Český Krumlov, f. OV KSČ Český Krumlov 1945-1990, k. 75, Zpráva o přijetí bývalého člena Jaroslava Jirky za kandidáta KSČ. Zpráva pro schůzi POV KSČ Český Krumlov (Report on the acceptance of former member Jaroslav Jirka as a candidate of the Communist Party of Czechoslovakia. Report for the meeting of the POV KSČ Český Krumlov), 27. 12. 1976.

55 Ibid., Zpráva o přijetí bývalého člena Františka Ondřicha za kandidáta KSČ. Zpráva pro schůzi POV KSČ Český Krumlov (Report on the acceptance of former member František Ondřich as a candidate of the KSČ. Report for the meeting of the chairing board of the OV KSČ Český Krumlov), 27. 12. 1976. Author's archive, author's interview with Milada Kalinová, 18. 3. 2019. 
uncover economic crime in agriculture in Strakonice. He operated under the code name "Lawyer" (,Právník") until he died in the late 1980s. ${ }^{57}$

Karel Zikmund is another expelled Party member who can be found in StB materials as a secret collaborator with the code name "Amateur actor" („Ochotník“). He was employed as a professional officer in the Czechoslovakian People's Army (Československá lidová armada, ČSLA) from 1950. From the mid-1960's onwards, he served as chairman of the District Committee of the Union for the cooperation with the Army (Svaz pro spolupráci s armádou, Svazarm) and subsequently as chairman of the District Committee of the National Front. He retired from this position in 1969. During the vetting process in 1970, he was expelled from the Party and took up a job as a master trainee at the agricultural construction company Agrostav Prachatice. Later he even became the director of the apprenticeship centre. He remained in this position until 1977, when the centre was closed down, and he was reassigned to the position of independent controller at Agrostav. His contacts and active life made him a perfect candidate for secret cooperation with StB. He started his cooperation in 1977. The State Security Service was not interested in his communications with other former communists but mainly in the information he gathered in the dramatic amateur theatre ensemble. It was primarily because of the two prominent "dissidents" were involved in the ensemble: Jan Urban and Karel Pecháček. Both of them worked as teachers at the Prachatice grammar school. In the 1977 they were fired from the school staff for refusing to sign the Anti-charter. ${ }^{58}$ They came into the spotlight of the local StB instantly. ${ }^{59}$

\section{Conclusions}

Turbulent changes marked the period following the defeat of the Prague Spring for many Czechoslovakian citizens including those from the very south of Bohemia. Some careers, especially of those publicly active party functionaries or intellectuals could easily follow the scenario of social marginalisation, professional degradation and surveillance as we know it from the fate of many exposed representatives of the Prague Spring. Nevertheless, this was far from being the only path designed for those expelled from the Communist Party.

For those selected, expulsion did not have to mean a definitive break with the KSČ. Moreover, beginning with the XVIth Congress, the Party openly declared its openness to reformed sinners. The positive discrimination against the workers and peasants and the willingness to engage publicly and repent for their transgressions played an important role.

$57 \quad A B S$, sb. TS/CB, sv. a. č. 11353, Antonín Hrach.

58 Reaction campaign led by the KSČ elites, involving many well-known members of cultural scene, condemning Charter 77, a critical civic initiative formed in late 1976 to draw the attention to human-rights violations in Czechoslovakia. 
In the local conditions of the district organisations, however, personal relationships, mutual animosities, old wrongs and personal vendettas played a key role. In many cases, it can be seen that political motivations were secondary, or in some cases even functioned as a proxy, and the ideologised language of party scrutiny was often used to settle personal scores. Mutual solidarity between the protagonists, therefore, played an indispensable role. While the representatives of local power stuck together in 1968, the protests against them were incapable of elementary cohesion and doomed to failure.

Due to particular local conditions, it was necessary that certain professions were given extra space. There was a permanent lack of doctors and qualified medical staff. It was, therefore, difficult to replace those who already worked in the area. For this reason, they could not be subjected to the same strict standards as others excluded.

I tried to show the fates of KSČ members who had to leave the Party after the fall of the Prague Spring. Despite considerable efforts, I have not been able, with a few exceptions, to obtain the testimonies of witnesses of the 1970 KSČ purging. ${ }^{60}$ Therefore, the data on which my study is based mainly on source research conducted in the funds of the Party's district committees in Český Krumlov and Prachatice, the funds of the Party's Regional Committee and also in the personnel files of the StB.

Vast numbers of appeals, complaints, denouncements and other forms of communication with the Communist Party provide us with rich and varied material for further research. This research can easily focus on the discursive changes that accompanied the power shift in the early 1970's, legitimisation and delegitimisation processes, and more psychological matters.

\section{BIBLIOGRAPHY}

\section{Archival sources}

Archiv bezpečnostních složek

sb. Svazky kontrarozvědného rozpracování - České Budějovice (KR/CB)

sb. Svazky tajných spolupracovníků - České Budějovice (TS/CB)

Státní oblastní archiv Třebon̆

f. Jihočeský krajský výbor KSČ (JKV KSČ)

Státní okresní archiv Český Krumlov

f. Okresní výbor KSČ Český Krumlov (OV KSČ Český Krumlov)

60 A large part of the actors is dead, some could not be traced and some refused to talk. 
Státní okresní archiv Prachatice

f. Okresní výbor KSČ Prachatice (OV KSČ Prachatice)

\section{Secondary Literature}

ČERNÁ, Marie a kol.: Prověrky a jejich místo v komunistickém vládnutí. Československo 1948-1989. Ústav pro soudobé dějiny AV ČR, Praha 2012

KOCIAN, Jiří a kol.: Dějiny Komunistické strany Československa IV (1969-1993).

Academia, Praha 2020

MAŇÁK, Jiří: Čistky v Komunistické straně Československa v letech 1969-1970.

Ústav pro soudobé dějiny AV ČR, Praha 1997

MAŇÁK, Jiř́: Od ústupu k porážce, od omezování k likvidaci. Postup „normalizace“ a jeho vyvrcholení v „očistë“ liberecké okresní organizace Komunistické strany Československa. Ústav pro soudobé dějiny AV ČR, Praha 2011

Redakce: Komunisté v Českém Krumlově vyslovují nedůvěru vedoucímu tajemníkovi. Jihočeská Pravda, 27. 3. 1968, p. 1

Sbornîk hlavních dokumentů XV. sjezdu KSČ 12.-16. dubna 1976. Svoboda, Praha 1976

SIKORA, Stanislav: Zo strany von! Čistky radového členstva KSČ na Slovensku roku 1970. In: ROGUL'OVÁ, Jaroslava a kol.: Adepti moci a úspechu: etablovanie elít v moderných dejinách. Jubileum Valeriána Bystrického. Veda, Bratislava 2016 SKALECKÁ, Veronika: Pardubice v období normalizace. Politika, kultura a média od srpna 1968 do listopadu 1989. Pavel Mervart, Červený Kostelec 2016 Stanovy Komunistické strany Československa schválené 12. sjezdem KSČ dne 8. prosince 1962, doplněné a upravené 13. sjezdem KSČ dne 4. června 1966. ÚV KSČ, Praha 1966

\section{Interviews}

Author's interview with Milada Kalinová, 18. 3. 2019

Author's interview with Marie Králíková, 28. 2. 2021

Author's interview with Karel Postl, 28. 4. 2018

Author's interview with Vladimír Šimeček, 27. 1. 2019

\section{Websites}

http://www.ceskatelevize.cz/ivysilani/10132488909-pred-25lety/209411000110923/

http://www.prachatice.eu/mudr-jan-antonin-mager/d-21065 